4-11-2016

\title{
The Multicultural Classroom
}

Timothy L. Heaton

Cedarville University, heatont@cedarville.edu

Follow this and additional works at: http://digitalcommons.cedarville.edu/education_presentations Part of the Education Commons

\section{Recommended Citation}

Heaton, Timothy L., "The Multicultural Classroom" (2016). Education Faculty Presentations. 276.

http://digitalcommons.cedarville.edu/education_presentations/276

This Local Presentation is brought to you for free and open access by DigitalCommons@Cedarville, a service of the Centennial Library. It has been accepted for inclusion in Education Faculty Presentations by an authorized administrator of DigitalCommons@Cedarville. For more information, please contact digitalcommons@cedarville.edu. 


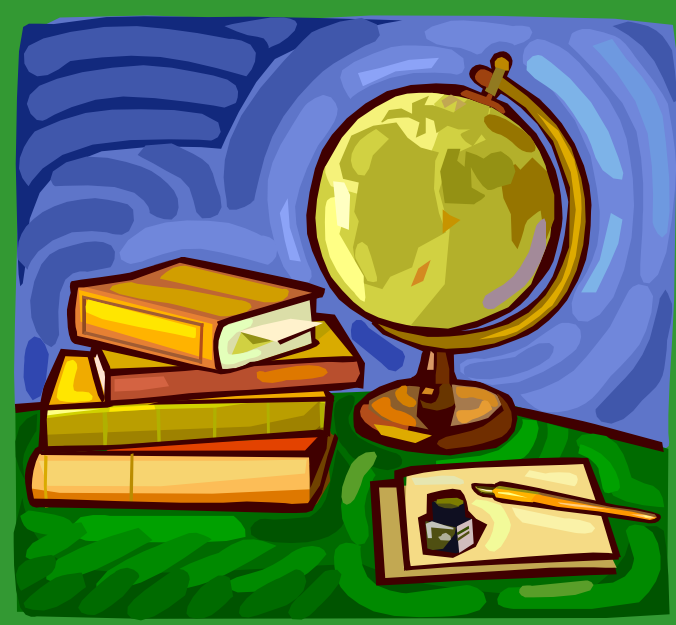

\section{Presented by:}

Dr. Timothy L. Heaton

Cedarville University

\section{Heatont@Cedarville.edu}

Based on research by Karen Balster 


\section{A Multicultural Classroom}

\section{is...}

one in which both the students and the teacher are accepting of all races, cultures, and religions. This acceptance is evidenced by the books that are read, the activities that are completed, and the lessons that are taught.

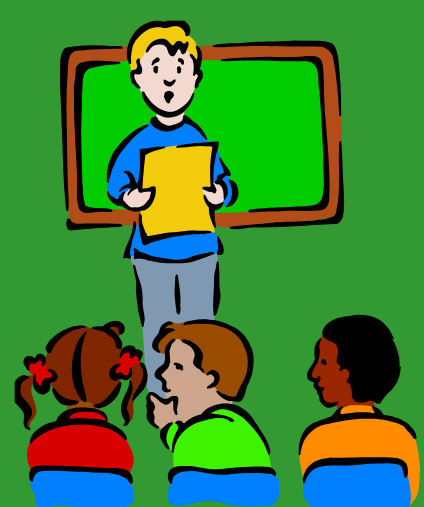




\section{Did you know that...}

of the $41 \%$ of teachers nationwide with ELLs in their classrooms, only $12.5 \%$ participated in 8 or more hours of professional development related to ELLs in in the past 3 years.

\section{Source: $\underline{\text { www.ncela.gwu.edu }}$}

-What are the characteristics of the bilingual education and ESL teacher shortage?

•Brown \& Menken, August 2002

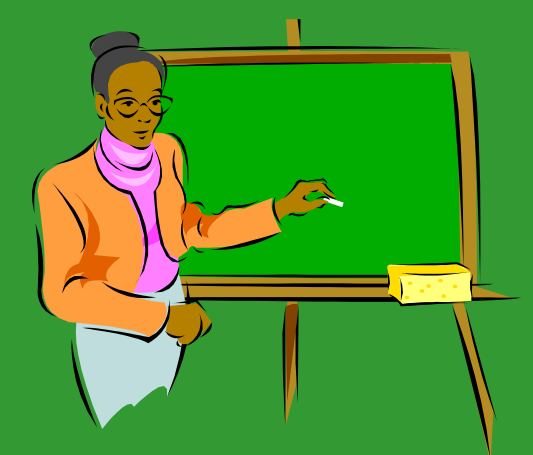




\section{Also...}

$>$ The majority of white primary and secondary school students have no significant contact with Black, Hispanic, peoples of other religions and customs from around the world and most of all nor American Indian

students
classroom.

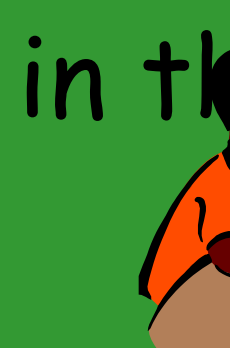




\section{General Strategies}

$>$ Recognize the demographics of your area and study the culture of that area.

$>$ Recognize any biases or stereotypes you may have absorbed.

$>$ Treat each student as an individual, and respect each student for who he or she is.

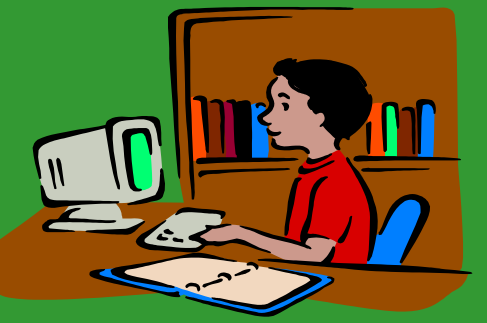




\section{More strategies...}

$>$ Rectify any language patterns or case examples that exclude or demean any groups.

$>$ Do your best to be sensitive to terminology. Eubonics ( Black English), Language differences, custom differences.

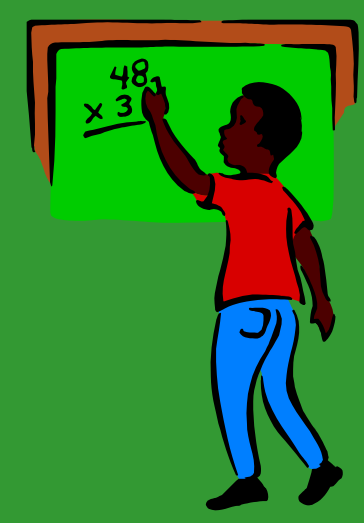




\section{Language Differences}

- $\underline{\text { https://www.youtube.com/watch?v=pkzVO }}$ $\underline{\mathrm{XKXfQk}}$

- https://www.youtube.com/watch?v=fhAiTu $\underline{\mathrm{TI} 8 \mathrm{VS}}$

- http://www.d.umn.edu/ hild0078/neweboni csbook4web.pdf 


\section{And finally...}

$>$ Get a sense of how students feel about the cultural climate in your classroom.

$>$ Introduce discussions of diversity at departments meetings.

$>$ You as the Principal "Teacher" ner to be a model to your staff. 


\section{Multicultural “ideas”}

$>$ Each month or quarter, 'adopt' a country.

$>$ Have a Show and Tell week focused on students' ancestry.

$>$ Team-teach a unit with an ESL instructor at your school.

$>$ When studying health and nutrition, study diets of different cultures. 


\section{Other Resources}

$>$ Teachers First

http://www.teachersfirst.com/multicult.htm

$>$ Teacher's Corner

http://www.edchange.org/multicultural/teachers.html

$>$ New Horizons for Learning

http://www.newhorizons.org/strategies/multicultural/front multicultural.htm

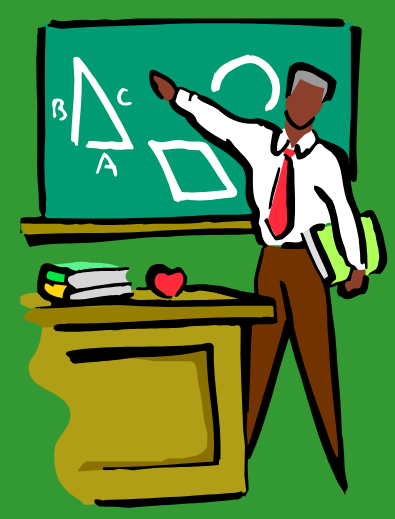




\section{Bibliography}

$>$ Multicultural Classroom

www.pre-kpages.com/multicultural.html

$>$ An Academic Overview of Desegregation

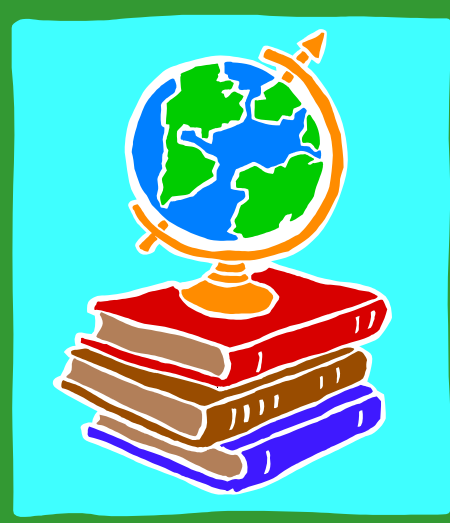
www.kirwaninstitute.org/multimedia/presentations/47\%20CLE\%20Final.ppt

> PBS TeacherSource

http://www.pbs.org/teachersource/

$>$ National Clearinghouse for English Language Acquisition and Language Instruction Education Program

uww.ncela.gwu.edu

$>$ Tools for Teaching by Barbara Gross Davis, University of California, Berkeley

http://teaching.berkeley.edu/bgd/diversity.html 